\title{
The radiolarian fauna during the Younger Dryas-Holocene transition in Andfjorden, northern Norway
}

\author{
Kjell R. Bjørklund ${ }^{1}$, Svetlana B. Kruglikova ${ }^{2}$ \& Øyvind Hammer ${ }^{1}$ \\ ${ }^{1}$ Natural History Museum, University of Oslo, Oslo, Norway; \\ ${ }^{2}$ P.P. Shirshov Institute of Oceanology, Russian Academy of Sciences, Moscow, Russia
}

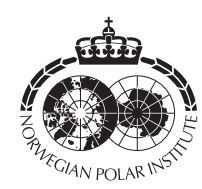

\begin{abstract}
We report on the changing radiolarian faunas from the Younger Dryas (ca.12.9 calibrated thousands of years BP [cal. Ky BP]) and into the Holocene (ca. 10.3 cal. Ky BP) in the core JM99-1200 from Andfjorden, northern Norway. Temperature reconstructions using both the Q-mode factor analysis and modern analogue technique methods show stable, cold temperatures below ca. $410 \mathrm{~cm}$ core depth, followed by abrupt warming into a relatively stable Holocene temperature regime. Age-depth modelling with three different methods gives an age of ca. 11.9-12.0 cal. Ky BP at this core depth, clearly older than the Younger Dryas-Holocene transition at ca. 11.65 cal. Ky BP according to ice core chronology. Considering that the age models may be insufficiently informed in an interval without radiometric dates, it is possible that the base of the Holocene is indeed at $410 \mathrm{~cm}$, as indicated by the radiolarian and other core data. Such a change in the chronology would have implications for previously published work on the JM99-1200 core. Alternatively, the abrupt warming in Andfjorden predated the Younger Dryas-Holocene transition by a few hundred years. A distinct cold pulse at ca. 315-335 cm, or 11.4-11.5 cal. Ky BP is interpreted as the Preboreal Oscillation. The Preboreal Oscillation has not previously been detected in temperature curves based on planktic foraminifera in the same core, indicating that Radiolaria may be a more sensitive temperature indicator in this region.
\end{abstract}

To access the supplementary material, please visit the article landing page

\section{Keywords}

Palaeoclimate; biostratigraphy; age models; Preboreal Oscillation; transfer functions

\section{Correspondence}

Øyvind Hammer, Natural History Museum, University of Oslo, PO Box 1172 Blindern, NO-0318 Oslo, Norway. E-mail: ohammer@ nhm.uio.no

\section{Abbreviations \\ BoA: Boreal assemblage; AMS: accelerator mass spectrometry; ${ }^{14} \mathrm{C}$ yr BP: uncalibrated years before 1950; CA: correspondence analysis; CABFAC: Calgary and Brown (Q-mode) factor analysis; cal. Ky BP: calibrated thousands of years before 1950; cal. yr BP: calibrated years before 1950; CCA: canonical correspondence analysis; GICC05: Greenland Ice Core Chronology 2005; LPA: Late Preboreal assemblage; MAT: modern analogue technique; PBO: Preboreal Oscillation; PCOA: Preboreal Climatic Optimum assemblage; POA: Preboreal Oscillation assemblage; RMSEP: root mean square error of prediction; SST: sea-surface temperature(s); UPGMA: unpaired group moving average clustering method; YDA: Younger Dryas assemblage; WA-PLS: weighted average partial least squares method}

\section{Introduction}

The Nordic seas is an area of great importance for better understanding of the global climatic development. This is a key area for the maintenance of the North Atlantic thermohaline circulation and thus for the "Great Conveyor" of the World Ocean (e.g., Broecker 1997).

The time interval of interest, which is covered by the sediment column studied, represents two extreme ecological situations: the colder conditions that were dominant during the Younger Dryas, and the interglacial conditions dominant during the Preboreal (Eldevik et al. 2014). The Younger Dryas was terminated by a rapid climatic turnover event that took place over just a couple of decades (e.g., Mayewski et al. 1993), leading into the present Holocene interglacial, a period that, generally speaking, has had fairly stable climatic conditions.
The configuration of the Arctic Ocean and the Nordic seas differed significantly from the Last Glacial Maximum to the present-day situation. At present, the bathymetry of the continental shelf directs currents across small glacial highs and troughs, resulting in a well-oxygenated water column (Hald \& Vorren 1984). In the deep troughs, crossing the continental shelf, topographically controlled upwelling causes profound vertical mixing of the nutrient-rich water masses (Slagstad et al. 1999), causing high organic productivity in the surface waters, with reported values of up to $75 \mathrm{~g} \mathrm{C} \mathrm{m}^{-2} \mathrm{y}^{-1}$ (Wassmann et al. 1999). Primary production has changed significantly from fully glacial conditions with low primary production to the warm and fairly stable Holocene conditions with high primary production. This is shown in the appearance of, for example, the specific sea-ice diatom proxy IP25 at ca. 12.9 cal. Ky BP in the sedimentary record in core 
JM99-1200, defining the onset of the Younger Dryas stadial (Cabedo-Sanz et al. 2013). The presence of IP25 gives a qualitative measure of the presence of seasonal sea ice.

The first occurrence of radiolarians in Norwegian Sea sediments after the Last Glacial Maximum was reported by Jansen \& Bjørklund (1985) to represent the Allerød according to their age model. On the basis of their mapping of coldwater radiolarian species (Cycladophora davisiana davisiana and Amphimelissa setosa), Jansen \& Bjørklund placed the maximum occurrence of these radiolarians in the Younger Dryas. Radiolarians and diatoms occurred at the same time, indicating that these siliceous microfossils were introduced by the increasing volume of intruding warmer North Atlantic water.

Radiolarians are ideal for recording abrupt environmental changes in water masses. An example will illustrate this (Bjørklund et al. 2012). In March 2009, a warm water pulse was recorded west of Spitsbergen, the largest island of the Svalbard Archipelago, with water temperature at $100 \mathrm{~m}$ depth measured to $7.5^{\circ} \mathrm{C}$. Subsequently, in August 2010, 145 radiolarian taxa were extracted from plankton sampled north of Spitsbergen and the island of Kvitøya. Of these 145 taxa, 98 were typical warm water species, some even with tropical-subtropical affinity. This indicates the potential of radiolarians to give an early and direct signal of environmental changes. Growth stages of some of these exotic species indicated that despite coming from much warmer conditions further south, they can still live and reproduce in these harsh conditions. However, such warm pulses do not last long enough to give these intruders a chance to accommodate to the new environments, and they will sooner or later perish.

The JM99-1200 core studied here is located in a climatically sensitive area, on the continental shelf on the west coast of northern Norway (Fig. 1). Normally, shelf sediments are barren of radiolarians or have a low amount of biogenic silica. However, in this core opal is relatively common, and diatoms and radiolarians are found together, indicating very high primary production. Under such conditions, biogenic opal is well preserved.

The radiolarian fauna in JM99-1200 has been subjected to a detailed taxonomical study and a statistical evaluation carried out in an attempt to recognize specific groups indicating different ecological conditions from the Younger Dryas and into the Holocene. Our aim is to get a better understanding of the development of the radiolarian faunas in these high northern latitudes and how they can improve our understanding of past oceanographic development. In particular, we wanted to compare the temperature signal derived from the radiolarian faunas with other temperature proxies, to refine previously described environmental interpretation of this important

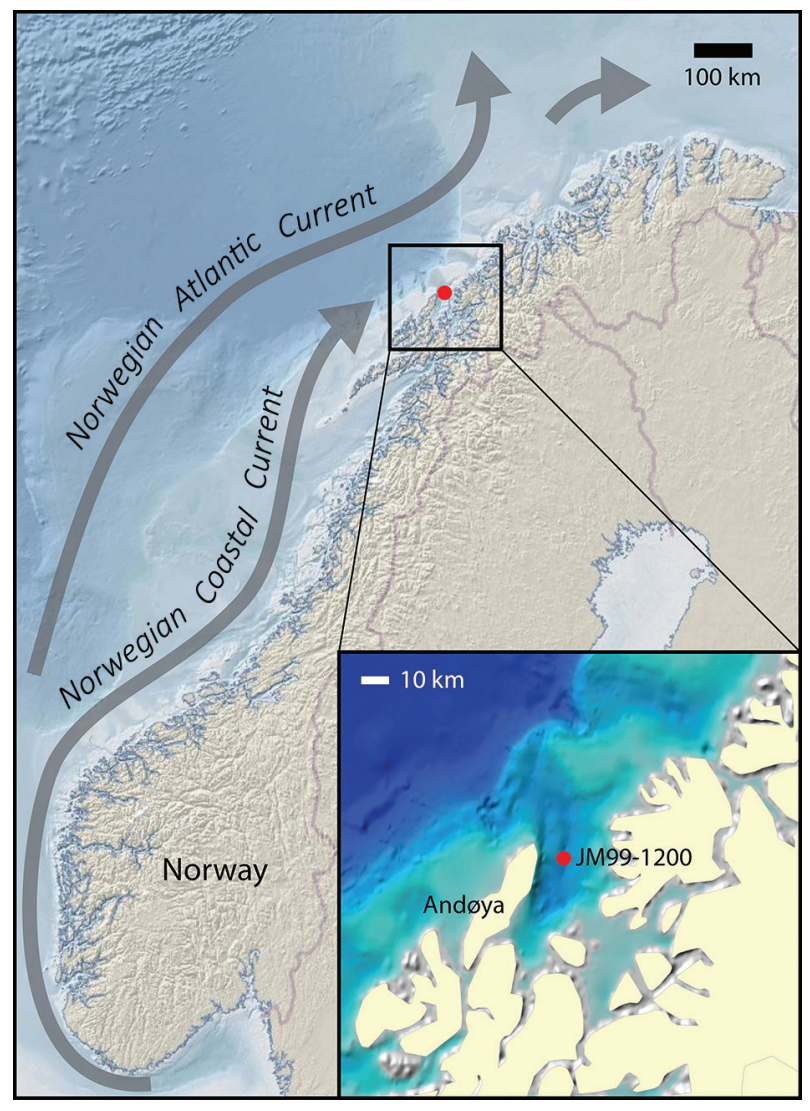

Fig. 1 The coring location of core JM99-1200 in Andfjorden, northern Norway, along with the major ocean currents. Based on the General Bathymetric Chart of the Oceans maps, licenced by CCBY 4.0, with our own annotations.

core (Knies et al. 2003; Ebbesen \& Hald 2004; Knies 2005; Cabedo-Sanz et al. 2013).

\section{Material and methods}

\section{Study site}

Piston core JM99-1200 was recovered from Andfjorden, northern Norway $\left(69.16^{\circ} \mathrm{N}, 16.25^{\circ} \mathrm{E}\right.$; water depth $475 \mathrm{~m}$; core length $1115 \mathrm{~cm}$ ), on board the RV Jan Mayen in November 1999. Andfjorden is at present under the influence of two current systems: the warm and saline Norwegian Current (the continuation of the North Atlantic Current, also called the Gulf Current) and the overlaying shallow (50-100 m) Norwegian Coastal Current (Fig. 1). The latter originates from the brackish Baltic Sea and is nourished by low salinity water from the fjords and river discharge as it moves northward along the coast. According to Hald \& Vorren (1984), SSTs in Andfjorden vary in August between 9 and $12{ }^{\circ} \mathrm{C}$ and in February 
between 2 and $6{ }^{\circ} \mathrm{C}$, which is in great contrast to the Arctic and icy conditions during the Younger Dryas stadial, when the Norwegian Coastal Current had not yet developed. The coring site is situated in a glacial trough at the mouth of an open sound, relatively close to shore but not in a restricted fjord setting.

\section{Taxonomy and sample preparation}

The radiolarian faunas in the Nordic seas have been analysed by several researchers, most studies dealing essentially with their taxonomy (Cleve 1899, 1900; Jørgensen 1900, 1905; Schröder 1909, 1914). Petrushevskaya \& Bjørklund (1974) reported on 74 radiolarian species in their study of the Norwegian and Labrador seas, while Bjørklund et al. (1998) reported on 75 taxa from the Nordic seas. In recent years, the radiolarian taxonomy in the type collection of Cleve (stored in the Swedish Museum of National History, Stockholm) was examined by Bjørklund et al. (2014) and the collection by Jørgensen (stored at the Natural History Museum, University of Oslo) was studied by Dolven et al. (2014), with an updated taxonomic discussion and illustration of all recognized types. In general terms, we can say that the average number of species typical for the Nordic seas is about 75 taxa.

The 55 samples were prepared for radiolarian studies according to the method outlined in Goll \& Bjørklund (1974). Samples were boiled in $\mathrm{H}_{2} \mathrm{O}_{2}$, sieved on a $45 \mu \mathrm{m}$ screen, residue treated with $\mathrm{HCl}$ and rinsed in distilled water. Two faunal slides, embedded in Canada Balsam, were made from each sample (Figs. 2, 3). A total of 91 radiolarian taxa was identified and counted to determine their relative abundance. A higher number of radiolarian taxa is observed in our Preboreal section than the average number of recent Norwegian Sea taxa (ca. 75). This is probably a result of the examination of many samples related to the warm Preboreal covering a time span of about 1000 years and therefore picking up a higher number of exotic and rare taxa than at present. An average of 481 specimens were counted (maximum 1023, minimum 70), including two groups of unidentified spumellarians and nassellarians, to calculate the taxa relative abundance values (Fig. 4).

\section{Statistical analyses}

A quantitative partitioning of the studied interval according to radiolarian assemblages was performed using stratigraphically constrained UPGMA clustering with Bray-Curtis similarity, as implemented in Past, version 3.25 (Hammer et al. 2001). Species richness and diversity were also calculated with Past. Raw species richness is highly sensitive to counted sample size, which varies strongly in our data set. We, therefore, standardized the sample size to $n=60$ using the rarefaction method (Krebs 1989). Simpson's $D$ (dominance) is here reported in its complementary form $1-D$.

Temperature reconstructions were based on the coretop abundances of 34 selected radiolarian taxa from the North Atlantic (Kruglikova et al. 2010). Kruglikova et al. found that the cleanest signal was achieved when correlating the faunas with the present-day temperatures at $200 \mathrm{~m}$ water depth (also confirmed by Matul \& Mohan 2017). We used April-June temperatures from the World Ocean Atlas 2001 (Boyer et al. 2004) as this is the season of maximal radiolarian productivity. Kruglikova et al. (2010) noted that temperature reconstructions based on radiolarians in the North Atlantic seemed almost unaffected when performing the analysis on family-level rather than species-level taxa, resulting in considerably simpler and faster counting. However, we used the species-level data in this study. Three methods were used, all implemented in Past version 3.25 (Hammer et al. 2001). The transfer function approach used CABFAC with quadratic regression on temperature (Imbrie \& Kipp 1971), following Kruglikova et al. (2010). MAT used the same North Atlantic calibration data set, with $n=6$ neighbour averaging, inverse distance weighting and no distance thresholding. Finally, WA-PLS was based on the standard algorithm described by Ter Braak \& Juggins (1993).

CA of the radiolarian faunas was computed with Past, giving an ordination biplot with samples and taxa plotting in the same diagram. CA is a powerful tool for finding gradients, trends and groupings in multivariate count data (Legendre \& Legendre 1998). Rare taxa that were never represented by more than two specimens in any sample were left out of this analysis, in order to produce a more readable biplot showing the most important taxa $(n=54)$.

CCA (Legendre \& Legendre 1998) for the radiolarian faunas included a number of geochemical and sedimentological variables collected from the literature on the JM99-1200 core: the brassicasterol and IP25 biomarkers (Cabedo-Sanz et al. 2013); total organic carbon, $\mathrm{CaCO}_{3}$ and $\delta^{13} \mathrm{C}_{\text {org }}$ (Knies et al. 2003); $\delta^{13} \mathrm{C}$ and $\delta^{18} \mathrm{O}$ from planktonic foraminifera and ice-rafted debris $>2 \mathrm{~mm}$ (Ebbesen $\delta$ Hald 2004). Linear interpolation was used where sample depths did not correspond exactly between these variables and the radiolarian samples.

\section{Age model}

An age model for core JM99-1200 was first constructed by Knies et al. (2003) based on seven AMS ${ }^{14} \mathrm{C}$ dates. Ebbesen \& Hald (2004) used additional AMS ${ }^{14} \mathrm{C}$ dates and 


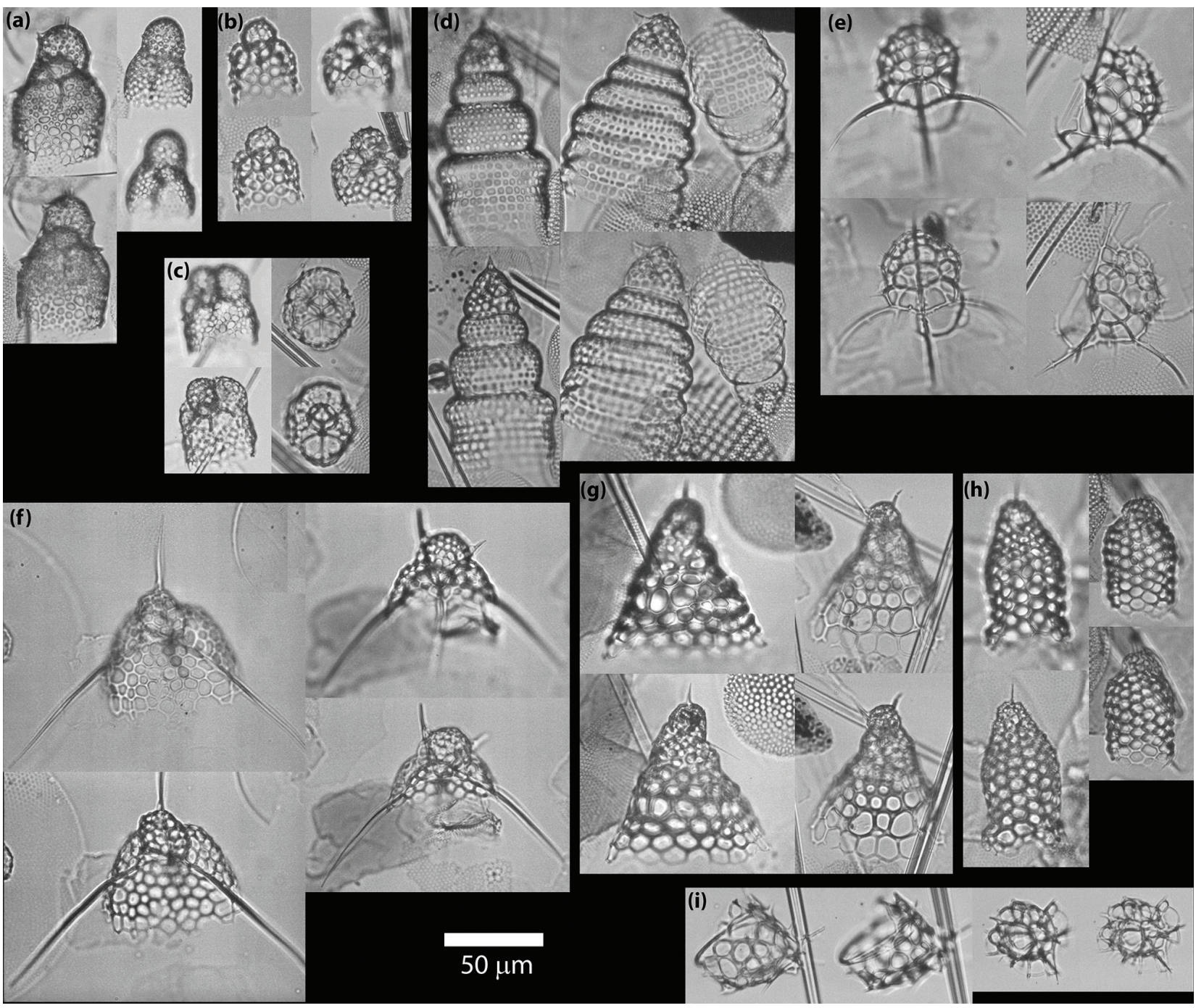

Fig. 2 Selected Radiolaria (Nassellaria) from core JM99-1200, with each species illustrated by two specimens, each at two focal planes: (a) Lithomelissa setosa, 335-336 cm and 330-331 core depth; (b) Lithomelissa hystrix, 280-281 and 335-336 cm; (c) Amphimelissa setosa, 330-331 and 280-281 cm; (d) Stichocorys seriata, 280-281 cm; (e) Phormacantha hystrix, 495-496 cm; (f) Pseudodictyophimus gracilipes clevei, 495-496 cm; (g) Cycladophora davisiana davisiana, 495-496 cm; (h) Sethoconus tabulatus, 495-496 cm; and (i) Plectacantha oikiskos, 335-336 cm.

the Vedde Ash tephra horizon, a time marker at $436.5 \mathrm{~cm}$ depth in the core. Cabedo-Sanz et al. (2013, their Table 1) finalized the age model by recalibrating the above-mentioned AMS ${ }^{14} \mathrm{C}$ dates using Calib version 6 (Stuiver et al. 2005) and the marine calibration curve Marine09 as outlined in Hughen et al. (2004) and Reimer et al. (2009). See Cabedo-Sanz et al. (2013) for more details about the marine reservoir age.

In this article, we have made some small adjustments to the age calibrations (Table 1), with the Marine13 calibration curve and using the delta $R$ values of Cabedo-Sanz et al. (2013). The calibration was carried out with OxCal version 4.3 (Bronk Ramsey 2009). The Vedde Ash has been moved from 11.980 to 12.121 cal. Ky BP according to GICC05 (Rasmussen et al. 2006), with a two-sigma error bar approximated by the total maximum counting error in GICC05 (Andersen et al. 2006). Relatively large error bars in the calibrated ages at 300.5 and $457.5 \mathrm{~cm}$ are due to plateaus in the Intcall 3 calibration curve at ca. 11.5 and $12.3 \mathrm{ka} \mathrm{BP}$ (Reimer et al. 2013).

Cabedo-Sanz et al. (2013) constructed their agedepth model by linear interpolation between the calibrated ages and did not take error bars into account. We have used two different techniques that weigh the data 


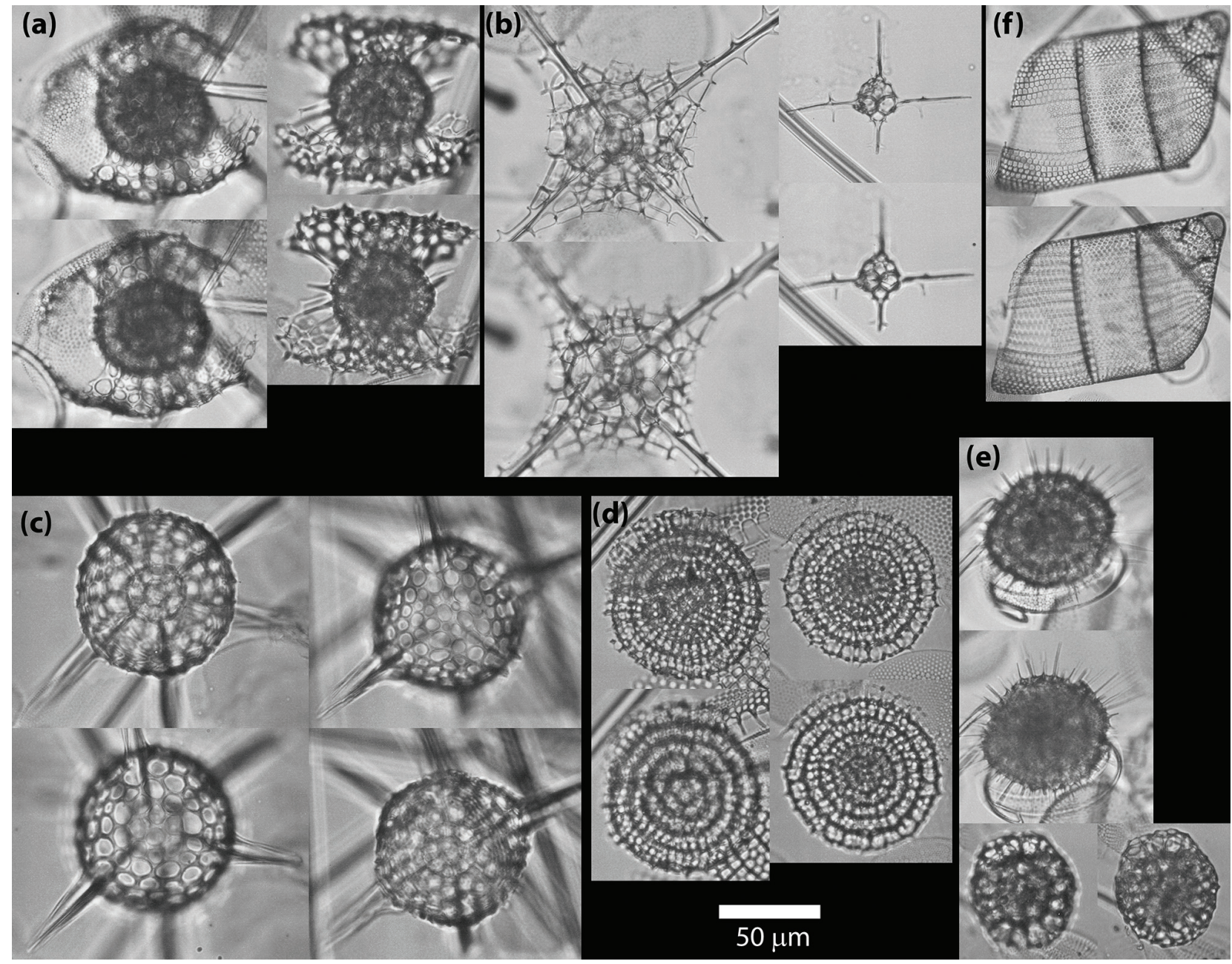

Fig. 3 Selected Radiolaria (Spumellaria) from core JM99-1200: (a) Phorticium clevei, 335-336 and 280-281 cm; (b) Cleveiplegma (Rhizoplegma) boreale, 330-331 cm; (c) Hexacontium gigantheum, 280-281 cm; (d) Stylodictya validispinaltenuispina, 280-281 cm; (e) Lithelius minor, 335-336 and 280-281 cm; and (f) diatom Isthmia nervosa, 335-336 cm.

points according to their errors, allow the age model to not pass exactly between the data points and produce confidence intervals. The smoothing spline interpolation follows the approach used for the radiometric age models in the International Geologic Time Scale 2012 (Agterberg et al. 2012) and was computed with Past, version 3.25 (Hammer et al. 2001). The "smoothing value," which controls how much the age-depth curve is allowed to depart from the given ages, is optimized by cross-validation. The confidence interval is constructed by Monte Carlo sampling from the given age distributions. The Bayesian age model was constructed with the Bayesian Poisson-process deposition modelling in OxCal (Bronk Ramsey 2008). The value of the parameter $\mathrm{k}$, which controls the degree of allowed variation in sedimentation rate, was allowed to vary from 0.01 to 100 events per $\mathrm{cm}$ (Bronk Ramsey \& Lee 2013). All calibrated ages reported in the results are taken from the OxCal age model and given in calendar years BP (i.e., before 1950), unless otherwise noted.

\section{Results}

\section{Radiolarian faunal assemblages}

Our section of the core investigated for radiolarians spans the time interval from the Younger Dryas through parts of the Boreal. The radiolarian fauna can be grouped into five definite assemblages (Fig. 5): (1) the Younger Dryas assemblage (YDA), (2) the Preboreal Climatic Optimum 


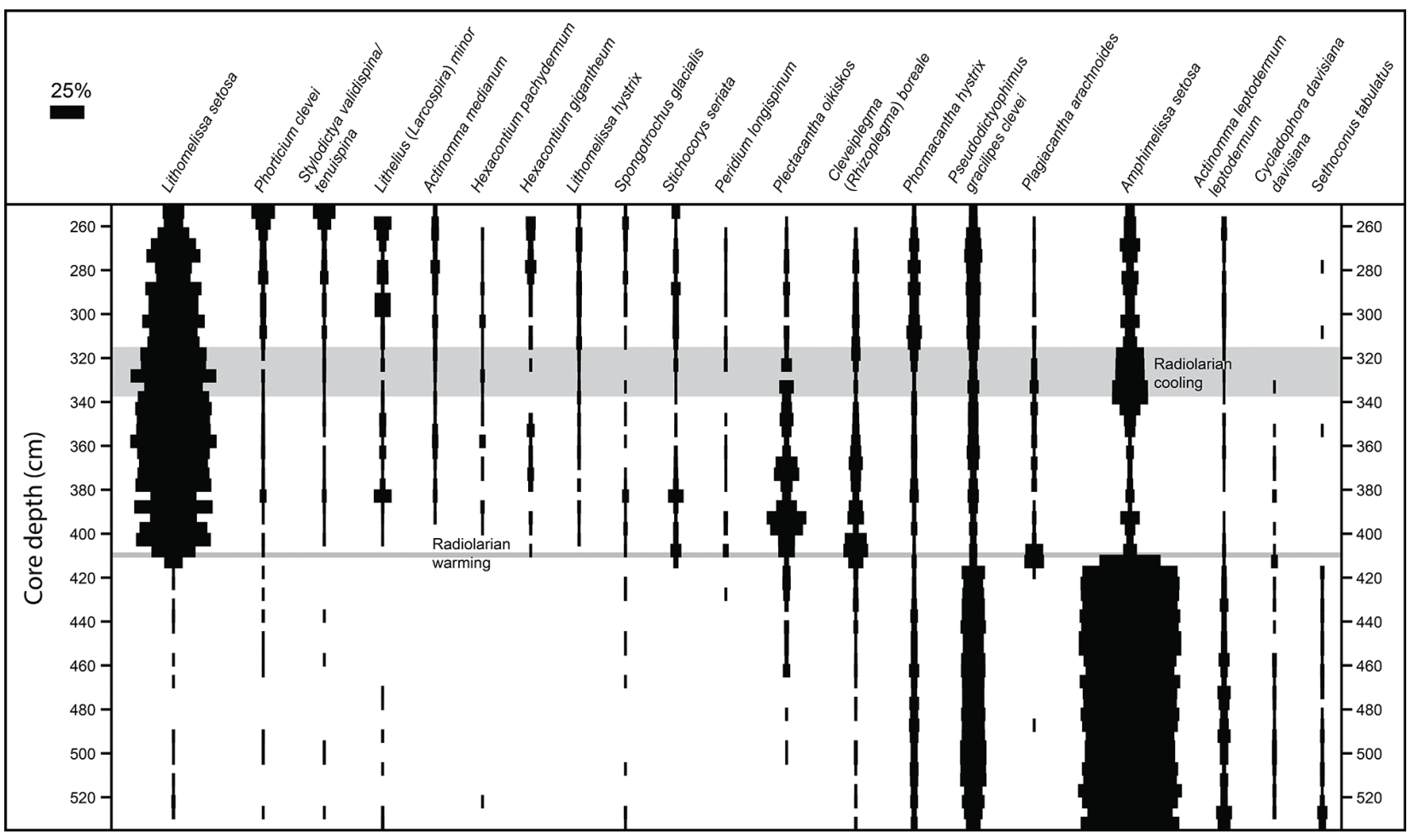

Fig. 4 Range chart of 20 selected radiolarian taxa in core JM99-1200.

Table 1 Dates used for the age model.

\begin{tabular}{lrcr}
\hline Core depth(cm) & C'4 age(BP) & $\begin{array}{c}\text { Cal. yr BP } \\
\text { (Cabedo-Sanz } \\
\text { et al. 2013) }\end{array}$ & $\begin{array}{c}\text { Cal. yr BP range } \\
(95.4 \%) \text { and mean } \\
\text { (this study) }\end{array}$ \\
\hline 59 & $5965 \pm 60$ & 6323 & 6180-6466 (6323) \\
281.8 & $10130 \pm 50$ & 10873 & $10690-11104(10897)$ \\
300.5 & $10510 \pm 85$ & 11429 & $11122-11780(11451)$ \\
436.5 (Vedde Ash) & & 11980 & $12121 \pm 114(2 \sigma)$ \\
457.5 & $11165 \pm 90$ & 12590 & $12124-12686(12405)$ \\
511 & $11460 \pm 85$ & 12880 & $12674-13088(12881)$ \\
655.5 & $11830 \pm 85$ & 13256 & $13056-13436(13246)$ \\
723.5 & $12160 \pm 80$ & 13553 & $13355-13766(13561)$ \\
\hline
\end{tabular}

assemblage (PCOA), (3) the Preboreal Oscillation assemblage (POA), (4) the Late Preboreal assemblage (LPA) and (5) the Boreal assemblage (BoA).

\section{Radiolarian diversity and palaeotemperature reconstructions}

Parameters computed from the radiolarian data are shown in Fig. 6. The different species richness and diversity indices correlate strongly, with low values in the lower part of the studied core interval $(535-415 \mathrm{~cm}$, YDA) followed by a sharp increase at $410 \mathrm{~cm}$ (YDA-PCOA). After a small dip in species richness around $325 \mathrm{~cm}$ (within the POA), diversity shows an increasing trend up to the top of the studied interval $(250 \mathrm{~cm})$.

Cross-validation of the reconstructed temperatures at $200 \mathrm{~m}$ water depth for the core-top data set gives an RMSEP of $1.01{ }^{\circ} \mathrm{C}$ using the CABFAC method, while the MAT method gives an RMSEP of $0.74{ }^{\circ} \mathrm{C}$. The WA-PLS method gives the lowest RMSEP of $0.81{ }^{\circ} \mathrm{C}$ when three partial least squares method components are included in the model. Reconstruction of SST resulted in RMSEP values of $1.65{ }^{\circ} \mathrm{C}$ (CABFAC), $1.06{ }^{\circ} \mathrm{C}$ (MAT) and $1.29{ }^{\circ} \mathrm{C}$ (WA-PLS), that is, somewhat poorer than at $200 \mathrm{~m}$, as also found by Kruglikova et al. (2010).

The radiolarian temperature reconstructions for 200 $m$ water depth with CABFAC and MAT are similar, indicating very low water temperatures $\left(0-1{ }^{\circ} \mathrm{C}\right)$ up to ca. $410 \mathrm{~cm}$, then relatively stable temperatures of around $3-6{ }^{\circ} \mathrm{C}$ in the upper part, again with a dip around $325 \mathrm{~cm}$ core depth. Again at $200 \mathrm{~m}$ water depth, WA-PLS shows similar cold temperatures (below $1{ }^{\circ} \mathrm{C}$ ) as the other two methods below $410 \mathrm{~cm}$ in the core, but in the upper part the WA-PLS temperatures are considerably warmer. In particular, the Preboreal Climatic Optimum samples from 345 to $405 \mathrm{~cm}$ yield temperatures $3-6{ }^{\circ} \mathrm{C}$ higher with the 


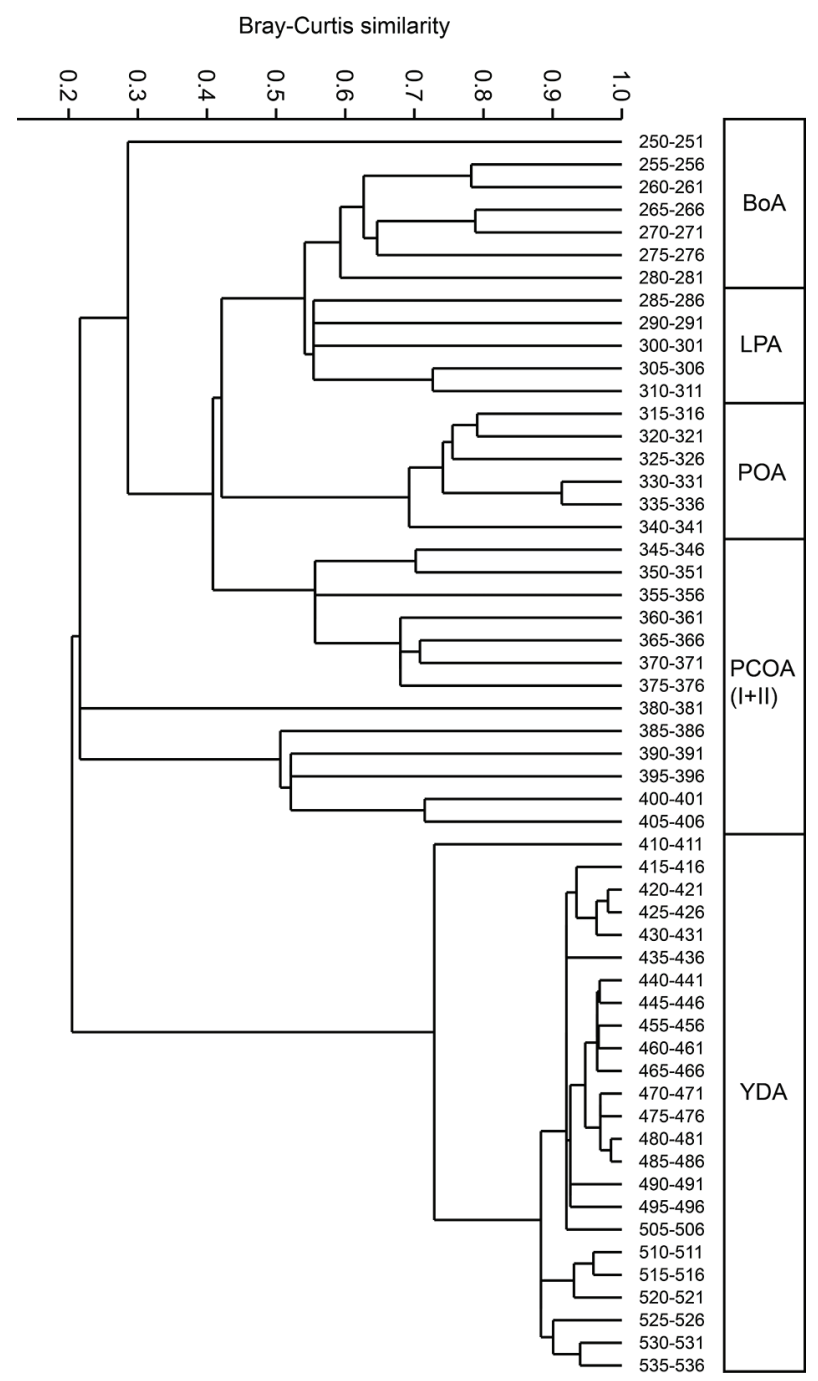

Fig. 5 Stratigraphically constrained cluster analysis of the radiolarian faunas (percentages), based on the Bray-Curtis distance.

WA-PLS method than the other methods, reaching $12^{\circ} \mathrm{C}$. The SST curve estimated from planktic foraminiferal faunas by Ebbesen $\&$ Hald (2004) is shown for comparison, with temperatures around $10{ }^{\circ} \mathrm{C}$ above $400 \mathrm{~cm}$ in the core.

The radiolarian temperature reconstructions for $0 \mathrm{~m}$ water depth (i.e., SST) have very similar trends as at 200 $\mathrm{m}$, but generally from 1 to $2.5^{\circ} \mathrm{C}$ warmer for the $\mathrm{CAB}$ FAC and MAT methods, and up to $5{ }^{\circ} \mathrm{C}$ warmer with WA-PLS, reaching $17^{\circ} \mathrm{C}$ in some of the PCOA samples.

\section{Correspondence analysis}

The result of the CA is shown in Fig. 7. Axis 1 (CA 1) contains $48 \%$ of total data chi-squared, while Axis 2 (CA 2) contains $20 \%$. These two axes, therefore, give a good representation of the data structure (total 68\%).

All the YDA samples $(535-415 \mathrm{~cm})$ cluster tightly at the left end of the plot (negative CA 1), while the younger samples are found at the right (positive CA 1). The 410-411 cm sample is transitional between these two groups. Taxa associated with the YDA samples in the plot include A. setosa, Sethoconus tabulatus, C. davisiana davisiana, Actinomma leptodermum leptodermum, Phormacanta hystrix and $A$. boreale. It may also be noted that among the younger samples with positive CA 1, the POA samples (335-315 cm) have the smallest scores. Comparing with the temperature analysis described above, it is natural to interpret CA 1 as loosely reflecting water temperature.

CA 2 discriminates mainly the post-YDA samples. There is a relatively clear trend from the oldest PCOA samples $(405-385 \mathrm{~cm})$ having the most negative CA 2 scores, to the youngest BoA samples $(260-250 \mathrm{~cm})$ with the most positive scores. The CA 2 scores do not correlate with inferred palaeotemperature but may reflect another environmental parameter.

\section{Canonical correspondence analysis}

CCA (Fig. 8) gives similar ordinated positions of samples and species as CA, but with opposite directions of the first two CCA axes (these directions are arbitrary). The first axis contains $73 \%$ of variation, while the second axis contains $19 \%$ of variation. Permutation tests give high significance $(p<0.01)$ for both these axes.

\section{Diatoms}

Diatoms have not been studied in detail, but a prominent change in the diatom assemblage occurs at ca. $295 \mathrm{~cm}$ core depth, within the upper part of the LPA interval (see Supplementary material). Below this depth, the assemblage is dominated by simple centric forms, while the upper part of the core contains large numbers of Isthmia nervosa (Fig. 3f). This species is an epiphyte on seaweeds such as Fucus and Laminaria, and has presumably been transported from littoral environments around the fjord.

\section{Age model}

As shown in Table 1, most of our newly calibrated ages differ by fewer than 25 years from those of Cabedo-Sanz et al. (2013), except the Vedde Ash, which is now 141 years older, and the $457.5 \mathrm{~cm}$ radiocarbon date, which is now 185 years older. The reason for the latter, large discrepancy is unknown. In any case, due to plateaus in the calibration curve, the error bars are large in this interval (Table 1). 

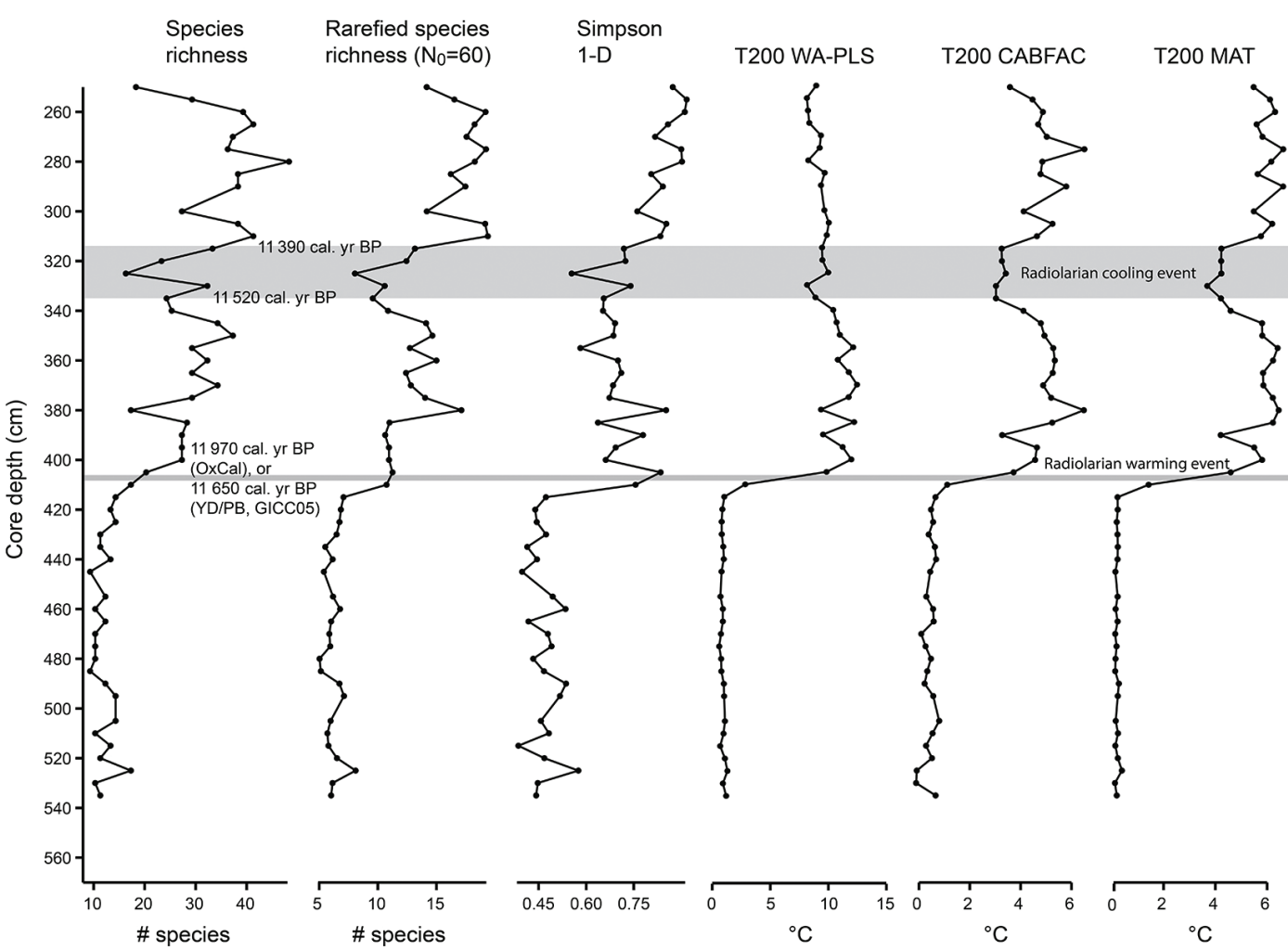

Planktic

foraminiferal SST

Fig. 6 Parameters derived from the radiolarian faunas in the JM99-1200 core. Species richness is the observed number of species. Rarefied species richness is standardized to a small sample size $N_{0}=60$. The Simpson index $D$ is a measure of numerical dominance of a few species, and conversely, $1-D$ is a measure of evenness. The reconstructed palaeotemperatures at $200 \mathrm{~m}$ water depth are shown for the WA-PLS, CABFAC and MAT methods. The reconstructed SST based on planktic foraminifera (Ebbesen \& Hald 2004) is included for comparison. Abbreviations: YD, Younger Dryas; PB, Preboreal.

The Bayesian age model is shown in Fig. 9. The maximum in the posterior distribution for $k$ was at $k=0.019$. This low value produces an age model that is similar to a linear interpolation through the individually calibrated dates, and with a relatively narrow confidence interval. The spline age model (Fig. 10) is similar to the Bayesian model, with a small optimized smoothing factor of 0.325 producing a tight fit to the points. The main difference between the two models is found around ca. $11.8 \mathrm{cal}$. $\mathrm{Ky}$ BP, where the spline model produces a marked sigmoidal curve as opposed to the straight line in the Bayesian model.

\section{Discussion}

\section{Radiolarian faunal assemblages}

The YDA (535-536 to $410-411 \mathrm{~cm}$, see Fig. 5) is dominated by a cold-water assemblage with $A$. setosa (41-77\%) as the dominant species. Jansen \& Bjørklund (1985) recorded this species in the filtered surface waters (3 m depth, ship's seawater inlet) on the Iceland Plateau, with a total dominance of up to $90 \%$. The temperature of the sampled surface water was about $+2{ }^{\circ} \mathrm{C}$, indicating a cold-water affinity for this species. Other common species are Pseudodictyophimus gracilipes clevei (9-17\%) and A. leptodermum leptodermum $(1-8 \%)$. Pseudodictyophimus gracilipes clevei is common in the present-day surface sediments in the Norwegian Sea, as well as in the Arctic Ocean, but other closely related forms are also present. These forms seem to be mostly associated with the warm water conditions in the Holocene. The assumed cold- and deep-water species C. davisiana davisiana $(0.2-3 \%)$ is never abundant in this assemblage but is found consistently in most samples. However, this species is reported to be a deep-water species, preferring depths of $1000 \mathrm{~m}$ or deeper. In the younger assemblages, C. davisiana davisiana is rare or absent. Finally, S. tabulatus $(0.2-6 \%)$ is consistently a characteristic member of the YDA and is only sporadically found in the other assemblages.

The PCOA (405-406 to 345-346 cm; Fig. 5) is dominated by Lithomelissa setosa (29-52\%), followed by a significant increase in Cleveiplegma (Rhizoplegma) boreale (15.6\% at 


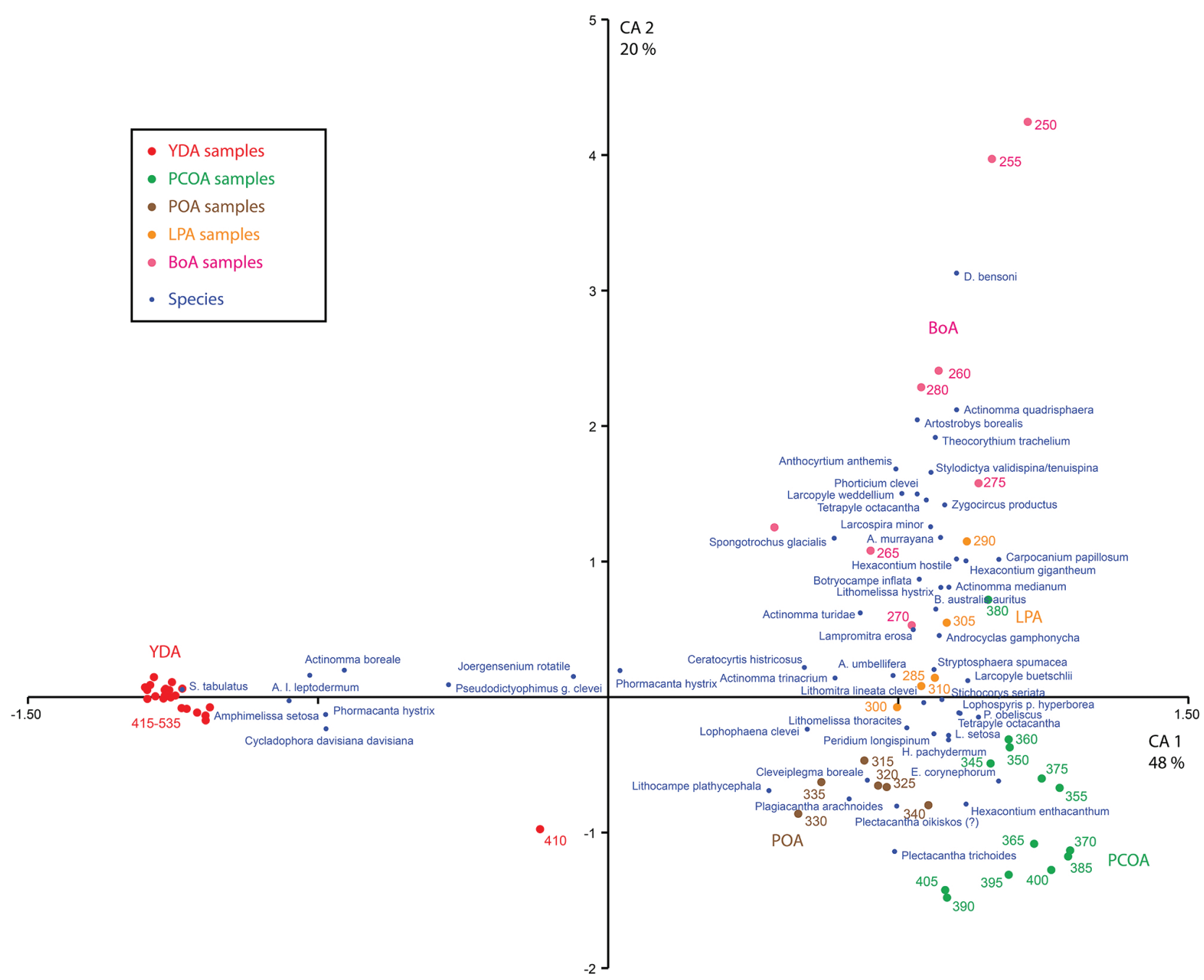

Fig. 7 CA of radiolarian faunas in core JM99-1200.

$405-406 \mathrm{~cm})$ and Plectacantha oikiskos? (10\% at 405-406 $\mathrm{cm}$, reaching $27 \%$ at $390-391 \mathrm{~cm}$, being most abundant in the lower part of PCOA). Cleveiplegma boreale is of special interest as Dolven \& Bjørklund (2001) reported on an early Holocene peak $\left(9880{ }^{14} \mathrm{C}\right.$ yr BP) in two cores HM79$6.2(9.2 \%)$ and HM97-6 (7.7\%) in the eastern Norwegian Sea, which most likely corresponds to the Preboreal occurrence herein and is therefore traceable along the west coast of Norway. On account of the high sedimentation rate in this core, the $C$. boreale peak has a larger vertical range than elsewhere.

The Younger Dryas-Preboreal transition is clearly marked by the sudden drop in A. setosa from 41 (410-41 1 $\mathrm{cm})$ to $8 \%(405-406 \mathrm{~cm})$. At the same transition there is a peak occurrence of Plagiacantha arachnoides with 11.9 and $10.8 \%$ in the $410-411$ and $405-406 \mathrm{~cm}$ samples.
Sethoconus tabulatus is only occasionally found in the Holocene, while it is present throughout the Younger Dryas sequence. Similarly, Stichocorys seriata is not observed in the Younger Dryas but is frequently found in the early Preboreal (maximum value $8.6 \%$ ).

The POA (335-336 to $315-316 \mathrm{~cm})$ is dominated by L. setosa $(38-57 \%)$, but $A$. setosa $(15-24 \%)$ is also an important faunal component. The latter species usually has a high number of symbionts within its protoplasm, indicating its near-surface habitat. Its sudden increase in abundance in this zone clearly indicates its sensitivity to ecological change, in this case a cooling event lasting for ca. 130 years (see age modelling below).

The LPA (310-311 to 285-286 cm) is only marked by the reduction in $A$. setosa, indicating a warming very similar to the late PCOA. 


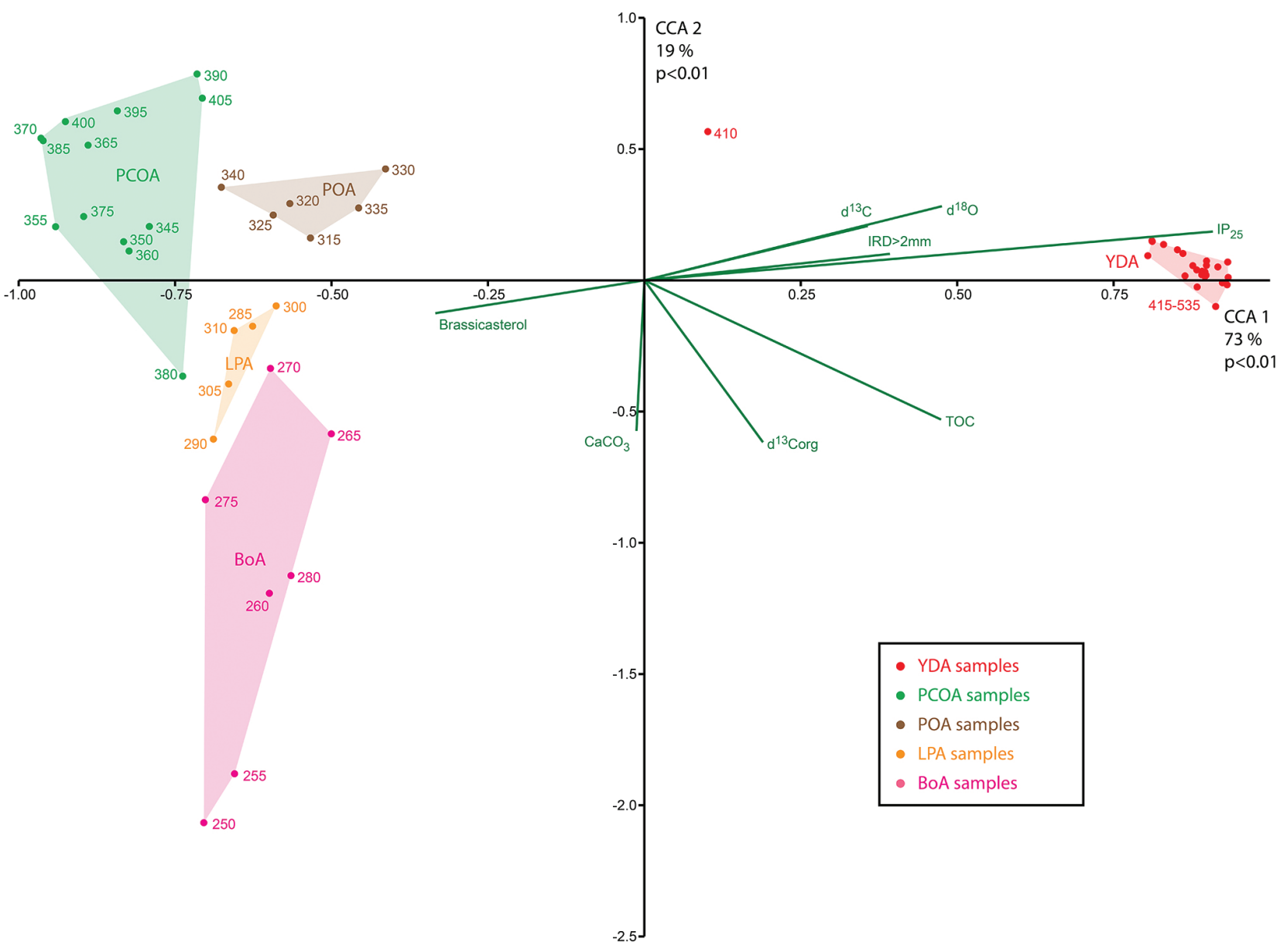

Fig. 8 CCA of radiolarian faunas in core JM99-1200

The BoA $(280-281$ to $250-251 \mathrm{~cm})$ is a radiolarian assemblage that is not very different from the LPA. The two assemblages are only weakly separated by cluster analysis and are distinguished here mainly because of a major change in the diatom composition. This assemblage is identified by a dominance of I. nervosa.

\section{Canonical correspondence analysis}

The inclusion of proxy variables in CCA allows palaeoenvironmental interpretation of the ordination axes. Especiallly IP25 (ice-cover proxy) and also ice-rafted debris correlate very strongly with the cold Younger Dryas radiolarian assemblage. The open marine phytoplankton biomarker brassicasterol points in the opposite direction and can, therefore, be understood as a warm water signal.

The second CCA axis correlates strongly negatively with marine palaeoproductivity proxies $\left(\mathrm{CaCO}_{3}\right.$, total organic carbon and $\delta^{13} \mathrm{C}_{\text {org }}$ ), although these signals are also controlled by sedimentation rates (Knies et al. 2003). We, therefore, interpret this axis as reflecting increased productivity from the Preboreal and into the Boreal radiolarian assemblages, with progressively negative axis scores.

\section{Palaeotemperature reconstructions: sensitivity to method}

The CABFAC and MAT methods give similar palaeotemperature reconstructions throughout the studied interval, and all three methods agree on the abrupt warming around $405-410 \mathrm{~cm}$ core depth. However, the WA-PLS method gives considerably warmer temperatures (up to $12{ }^{\circ} \mathrm{C}$ ) in the Holocene, especially in the PCOA samples. The reason for this discrepancy is mainly that the radiolarian faunas in the JM99-1200 core extend further in the direction of high temperatures than any of the samples in the training set from the North Atlantic. The highest 
measured temperature in the training set is $7.58{ }^{\circ} \mathrm{C}$, and only two of the 160 measurements are above $6{ }^{\circ} \mathrm{C}$. On the other hand, the important warm-water radiolarian species L. setosa never exceeds $19 \%$ in the training set, but reaches $88 \%$ in the core samples, for example.

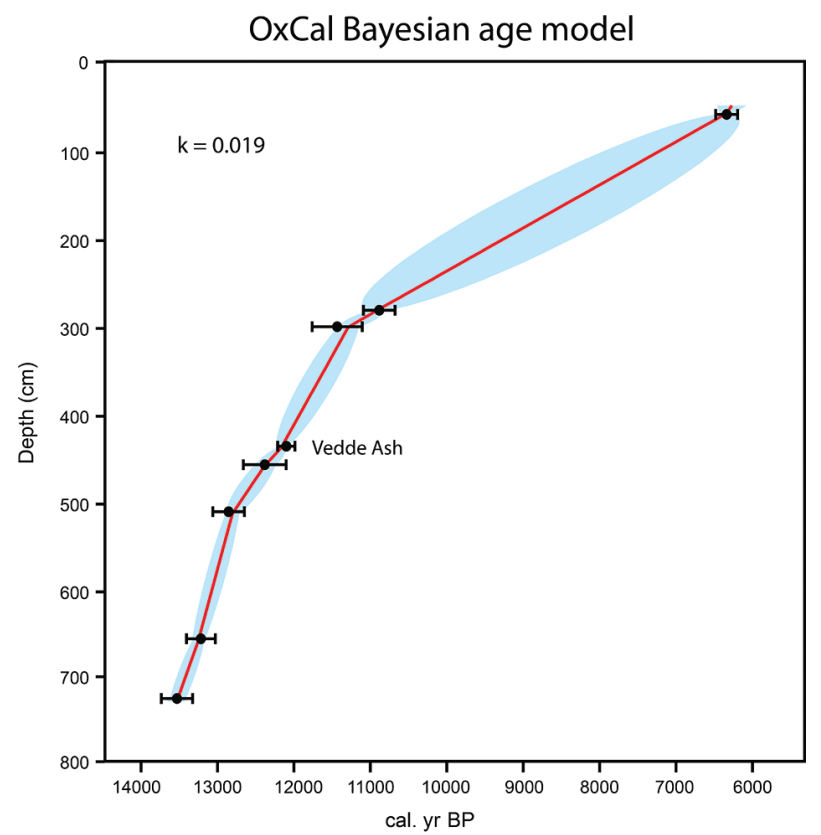

Fig. 9 Bayesian age model for JM99-1200 constructed with OxCal 4.3. Confidence intervals are 2-sigma (95\%).

\section{(a)}

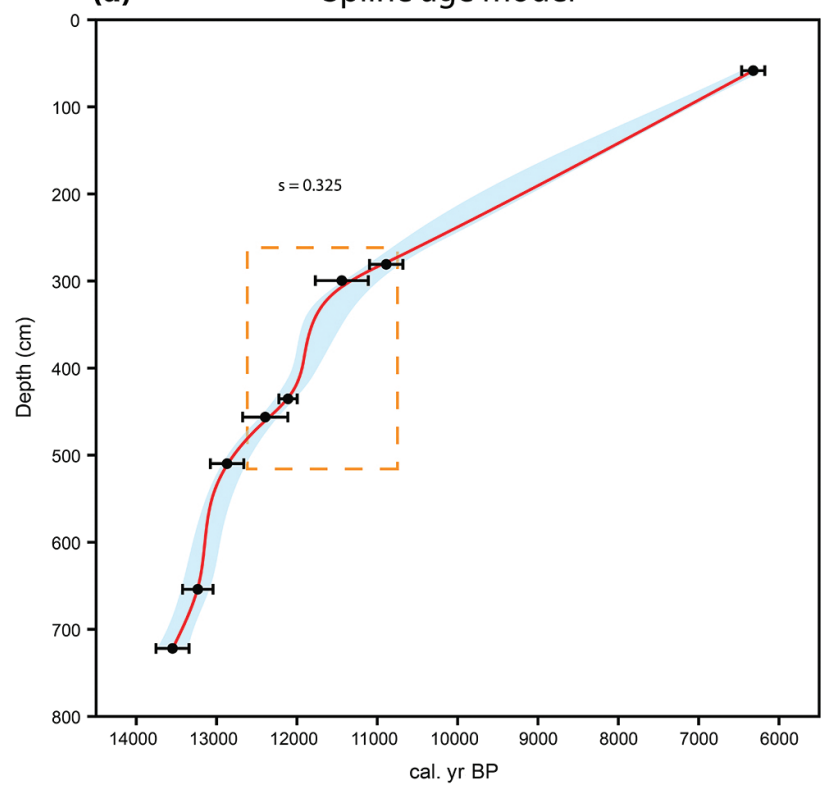

MAT is basically an interpolation method and can never produce temperatures higher than those in the training set. The CABFAC method with second-order fitting, as recommended by Imbrie \& Kipp (1971), will produce transfer functions that can flatten off towards the ends of the temperature ranges in the training set, also limiting the possible range of reconstructed temperatures. This contrasts with the WA-PLS method, which is capable of extrapolation. Whether this is a strength or a weakness of the WA-PLS method is debatable, but it is certainly possible that the extreme concentration of warm-loving radiolarian species in the Preboreal of Andfjorden indicates higher temperatures than in any of the modern sampling stations in the North Atlantic.

\section{Younger Dryas and the Younger Dryas-Preboreal transition}

Our temperature curves based on radiolarian faunas (Fig. 6) show very cold, stable temperatures (just above $0{ }^{\circ} \mathrm{C}$ ) below $410 \mathrm{~cm}$ core depth, in the Younger Dryas. The reconstructed temperatures based on planktic foraminifera (Ebbesen \& Hald 2004) are a few degrees warmer. This is partly because the radiolarian curves are calibrated to water temperatures at $200 \mathrm{~m}$ depth, while the foraminiferan curve is calibrated to surface temperatures. The radiolarian data then indicate a robust, clean and dramatic temperature increase around $405-410 \mathrm{~cm}$,

\section{(b) Zoom-in on spline model}

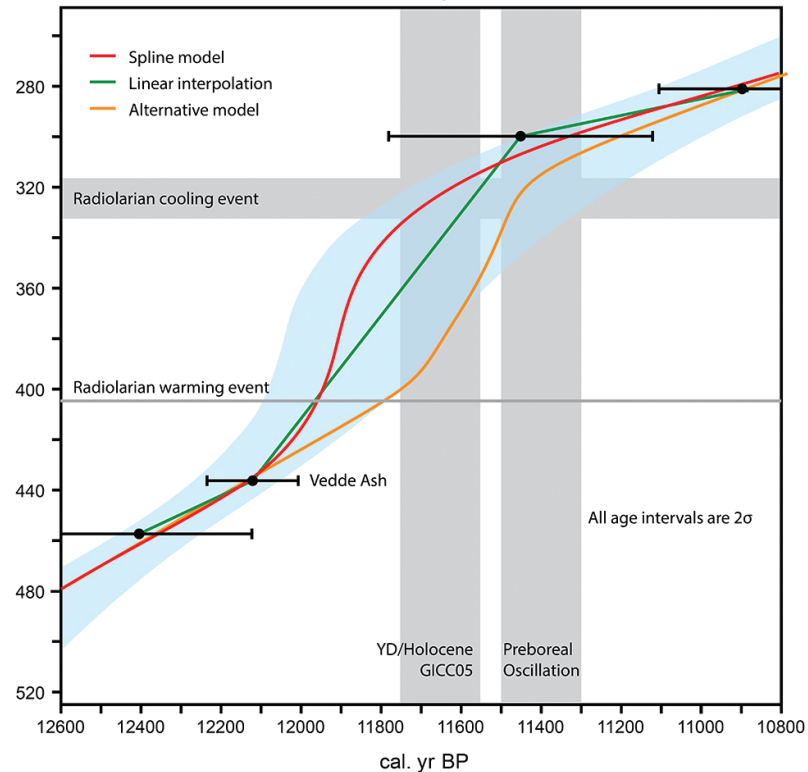

Fig. 10 (a) Age model for JM99-1200 constructed with the smoothing spline module in Past 3.25. (b) Zoom-in on part of (a), emphasizing the Younger Dryas-Holocene transition. 


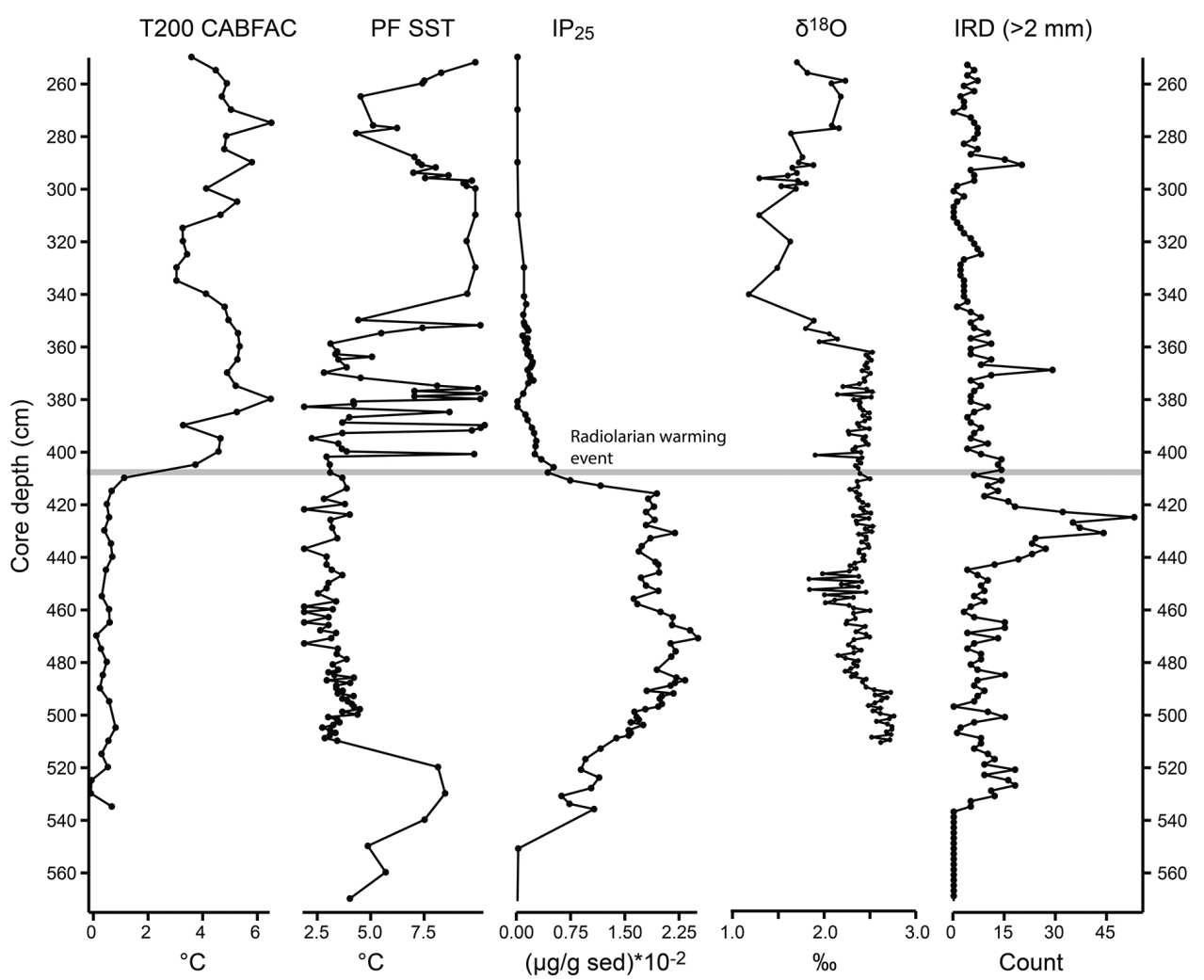

Fig. 11 Water temperature reconstructions compared with other logging parameters in core JM99-1200. Planktic foraminiferal faunal temperature curve (PF SST), foraminiferan oxygen isotopes $\left(\delta^{18} \mathrm{O}\right)$ and ice-rafted debris (IRD) curves from Ebbesen \& Hald (2004). IP25 ice-cover proxy curve from Cabedo-Sanz et al. (2013).

followed by relatively stable temperatures around $3-6{ }^{\circ} \mathrm{C}$ in the upper part (CABFAC and MAT).

However, the position in the core of the radiolarian response to the Younger Dryas-Preboreal transition presents a difficulty. According to GICC05, the age of the Younger Dryas-Preboreal boundary is $11653 \pm 99$ cal. yr BP (Rasmussen et al. 2006). The OxCal age model predicts this age at ca. $355 \mathrm{~cm}$ core depth, which is indeed close to the level of decreasing $\delta^{18} \mathrm{O}$ values in the planktic foraminifer Neogloboquadrina pachyderma (Fig. 11) as well as a level where the planktic foraminiferan temperature curve stabilizes at high values after fluctuating strongly in the 400-350 cm interval (Ebbesen \& Hald 2004). On the basis of these observations, Ebbesen $\&$ Hald (2004) and later authors (Cabedo-Sanz et al. 2013) placed the Younger Dryas-Preboreal boundary at ca. $330 \mathrm{~cm}$ depth in JM99-1200.

In contrast, the radiolarian data indicate a very sharp and clear temperature increase around $405-410 \mathrm{~cm}$, at an OxCal model age of ca. 11.9-12.0 cal. Ky BP. It is natural to interpret this event as the Younger Dryas-Preboreal transition. This is also supported by the ice-cover proxy
IP25, which indicates sudden loss of seasonal ice cover at ca. $410 \mathrm{~cm}$ core depth (Cabedo-Sanz et al. 2013), precisely at the radiolarian warming event (Fig. 11), and finally by the sudden increase in radiolarian species richness and diversity (Fig. 6). The problem with this interpretation seems to be the excessive age. We suggest that this problem is caused by weak constraints on the age model (Telford et al. 2004) in this interval, with no radiometric dates between 436.5 and $300.5 \mathrm{~cm}$ core depth. It is important to keep in mind that the variation in sedimentation rate between radiometric dates is fundamentally unknown and can never be accurately estimated by any statistical method. The purpose of an age-depth model based on radiometric dates is therefore to provide a most parsimonious (i.e., simplest possible) hypothesis, which is to be preferred over other hypotheses when no other information is available. An implication of this philosophy of parsimony is to assume a constant, or slowly varying, sedimentation rate between dates. As shown in Figs. 9 and 10, this approach, whether using the Bayesian, spline or linear interpolation procedure, leads to an age for the radiolarian warming event at $405-410 \mathrm{~cm}$ which is too 


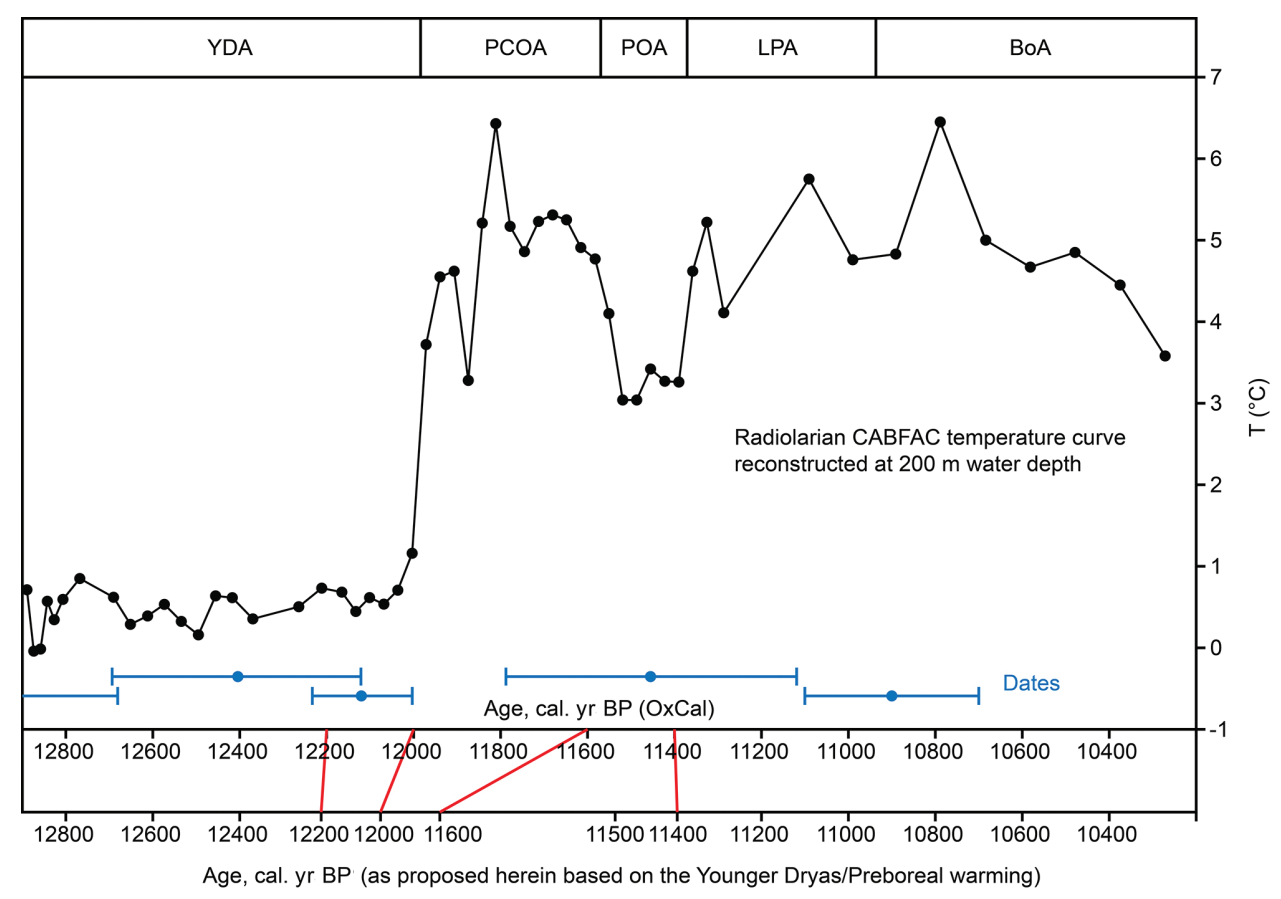

Fig. 12 Reconstructed temperature at $200 \mathrm{~m}$ water depth, based on radiolarian faunas, plotted against the OxCal age model and with our proposed ages. The POA is represented by a temperature drop of ca. $2^{\circ} \mathrm{C}$ in five samples. Radiolarian faunal assemblages are explained in the text.

old (i.e., displaced to the left) with respect to the accepted age for the Younger Dryas-Preboreal transition. However, there is no particular reason, except for the principle of parsimony, not to hypothesize an age-depth curve more similar to the "alternative model" shown in Fig. 10. We suggest that the very clear evidence for warming at 405$410 \mathrm{~cm}$ provides additional information which may be sufficient to adjust the age model in this way. There is little circularity in this argument, as rapid warming is almost the definition of the Younger Dryas-Preboreal transition. Indeed, a constant sedimentation rate through more than 1600 years, across the Younger Dryas-Preboreal transition, as implied both by the Bayesian and linear interpolation models, is not a likely scenario. In contrast, the alternative age model, as informed by the temperature data, implies a shorter episode of high sedimentation rate immediately after the termination of the Younger Dryas. This would be during the most rapid deglaciation phase, exactly where we would expect dramatically increased terrigenous sediment input. Figure 12 shows our radiolarian temperature curve, plotted against the OxCal age model and our suggested adjusted age model.

Ebbesen \& Hald (2004) used the fluctuation in foraminiferal temperature in the $400-350 \mathrm{~cm}$ interval to suggest an unstable Younger Dryas climate in the north-east North Atlantic. However, if the Younger Dryas-Preboreal transition is situated at $405-410 \mathrm{~cm}$ in the core, as we suggest, the 400-350 cm interval is in fact completely Holocene in age, not Younger Dryas. Moreover, a rapid temperature fluctuation in this interval is not supported by the radiolarian data, nor by the $\delta^{18} \mathrm{O}$ curve, which remains fairly stable until the rapid decrease at ca. $350 \mathrm{~cm}$ (Fig. 11). Regarding the $\delta^{18} \mathrm{O}$ values, Ebbesen $\delta$ Hald (2004) comment that the $\delta^{18} \mathrm{O}$ was taken from N. pachyderma (sinistral) only, which is a cold-water species that reflects the cold end-member of the water mass. Therefore, the recovered $\delta^{18} \mathrm{O}$ values could reflect mainly temperatures from short-term cold pulses or local cold-water pockets rather than regional and temporal averages. Also, salinity, which influences oxygen isotopes, may have varied substantially during the Younger Dryas-Holocene transition. The salinity curve of Ebbesen $\&$ Hald (2004) is calculated based on $\delta^{18} \mathrm{O}$ and the SST from the foraminiferal transfer function and is therefore subject to noise in the reconstructed SST.

In addition, if (as we suggest) the sedimentation rate was very high in this interval, the age difference between the Younger Dryas-Preboreal transition according to Ebbesen \& Hald (2004) and the radiolarian data presented here is in fact very small. Our suggested date for the Younger Dryas-Preboreal transition, based on the radiolarian temperature increase at $410 \mathrm{~cm}$, is 11653 \pm 99 cal. yr BP, taken from GICC05. Ebbesen \& Hald 
(2004) have their Younger Dryas-Preboreal transition at ca. $350 \mathrm{~cm}$ core depth, or ca. $11.5 \mathrm{ka}$ BP. Given that the disputed time interval could, therefore, be less than 150 years, the differences in the interpreted position of the Younger Dryas-Preboreal transition could be due to short delays in temperature response between the radiolarian and foraminiferal systems during the anomalous environmental conditions immediately after the transition. One consideration here is that the radiolarian record probably reflects temperatures mainly in deeper water masses (say below $150 \mathrm{~m}$ ) while the foraminiferan record is a shallower-water signal.

The alternative hypothesis - that the age of the warming at 405-410 cm core depth is indeed 11.9-12.0 cal. Ky $\mathrm{BP}$-does not require the somewhat ad hoc adjustment of the age model. This remains a possibility and would imply that the warming in Andfjorden took place a few hundred years earlier than the Younger Dryas-Preboreal transition recorded in the Greenland ice cores.

\section{The Preboreal Oscillation}

Our CABFAC and MAT temperature curves (Fig. 6) show a clear reduction in mean temperature from $5.0{ }^{\circ} \mathrm{C}$ in the $375-340 \mathrm{~cm}$ interval to $3.2{ }^{\circ} \mathrm{C}$ in the $335-315 \mathrm{~cm}$ interval. The WA-PLS reconstruction shows a less marked temperature drop. The temperature then returns to previous values above this interval. The reduced temperature is consistent in five consecutive samples. The OxCal age model predicts an age of 11.39-11.52 cal. Ky BP for this interval, which is fairly well constrained by the radiometric dates at 281.8 (10.90 cal. Ky BP) and $300.5 \mathrm{~cm}$ (11.45 cal. Ky BP). This age fits well with the PBO (e.g., Björck et al. 1997), which is placed at 11.4-11.5 cal. Ky BP in GICC05 (Rasmussen et al. 2007). As seen in Fig. 6, a corresponding temperature minimum is not visible in the temperature curve based on planktic foraminifera (Ebbesen $\&$ Hald 2004). If the minimum indeed represents the Preboreal Oscillation, then the Radiolaria seem to give a more sensitive temperature indicator than planktic foraminifera in this core. Knies et al. (2003) tentatively connected a small dip in marine organic carbon at ca. $11.0 \mathrm{cal}$. Ky BP (as adjusted to the age calibrations used here) in JM99-1200 to the PBO. This does not, however, seem to fit well with the new age for the PBO in GICC05. A dramatic temperature drop of almost $5{ }^{\circ} \mathrm{C}$ indicated by the planktic foraminifera in several samples around $280 \mathrm{~cm}$ core depth (Fig. 6) has a well-constrained age of ca. $10.9 \mathrm{cal}$. Ky BP, which is too young to represent the $\mathrm{PBO}$ and is not supported by the radiolaria. This is another feature of the planktic foraminiferan temperature curve which is difficult to reconcile with information from other localities.
A radiolarian-based temperature minimum that can be linked to the PBO was also reported by Matul \& Yushina (1999). In their core MK-340 from the Reykjanes Ridge, they found a robust, early Holocene temperature drop in the interval 10.7-10.1 cal. Ky BP (their calibration), but this age was constrained only by the two closest radiocarbon ages at 8.78 and $14.36 \mathrm{cal}$. Ky $\mathrm{BP}$, so an age corresponding to the PBO (11.4-11.5 cal. Ky BP) is still reasonable, as it would be within the error bars. Dolven et al. (2002) also observed a Preboreal temperature drop at 10.9-10.6 cal. Ky BP (their calibration) based on radiolaria in core MD95-2011 from the northern Norwegian Sea. This drop is confirmed by a reduction in abundance of the planktic foraminifer $N$. pachyderma (sinistral) in the same core (Risebrobakken et al. 2003). Haflidason et al. (1995) noted a minor temperature drop at ca. 11.2 cal. Ky BP in the core Troll 8903 in the northern North Sea, on the basis of N. pachyderma (s.) and linked this to the PBO.

\section{The Preboreal-Boreal transition}

The Preboreal-Boreal transition is not clearly identified by the radiolarian assemblages, although our cluster analysis (Fig. 5) indicates a possible radiolarian zone above the 280-281 cm level. We have, on the other hand, diatom information that indicates changing environments at this level in the core. Above this depth, the benthic and epiphytic diatom I. nervosa is the dominant species in the size fraction we have studied. Below this depth-centric diatoms are the dominant part of the flora, but I. nervosa is still present. The great amount of this shallow water (or littoral) diatom suggests a change in wind and wave erosion, making it possible to transport its valves to the deep core site.

\section{Conclusions}

The radiolarian data from core JM99-1200, from Andfjorden in northern Norway, indicate dramatic warming at $405-410 \mathrm{~cm}$ core depth, consistent with some other data, including the IP25 ice-cover proxy. We suggest that this event coincides with the Younger Dryas-Preboral transition. This hypothesis requires an adjustment of the age model, which we have argued can be defended on theoretical grounds. If this adjustment is accepted, it will imply re-interpretation of some previously published results. We have also identified a minor cooling event at 11.4-11.5 cal. Ky BP, which we interpret as the PBO.

\section{Acknowledgements}

The authors thank Dr Matthias Forwick, Department of Geosciences, UiT-The Arctic University of Norway, 
Tromsø, for making the core available to them. They also thank Giuseppe Cortese and Hans Petter Sejrup for useful comments on an early version of the article and to an anonymous reviewer for constructive suggestions.

\section{Disclosure statement}

The authors report no conflict of interest.

\section{References}

Agterberg F.P., Hammer Ø. \& Gradstein F.M. 2012. Statistical procedures. In F.M. Gradstein et al. (eds.): The geologic time scale 2012. Pp. 269-274, doi: 10.1016/C2011-1-08249-8. Amsterdam: Elsevier.

Andersen K.K., Svensson A., Johnsen S.J., Rasmussen S.O., Bigler M., Röthlisberger R., Ruth U., Siggaard-Andersen M.-L., Steffensen J.P., Dahl-Jensen D., Vinther B.M. \& Clausen H.B. 2006. The Greenland Ice Core Chronology 2005, 15-42 ka. Part 1: constructing the time scale. Quaternary Science Reviews 25, 3246-3257, doi: 10.1016/j. quascirev.2006.08.002.

Björck S., Rundgren M., Ingolfsson O. \& Funder S. 1997. The Preboreal Oscillation around the Nordic seas: terrestrial and lacustrine responses. Journal of Quaternary Science 12, 455-465, doi: 10.1002/(SICI) 10991417(199711/12) 12:6<455::AID-JQS316>3.0.CO;2-S.

Bjørklund K.R., Cortese G., Swanberg N. \& Schrader H.J. 1998. Radiolarian faunal provinces in surface sediments of the Greenland, Iceland and Norwegian (GIN) seas. Marine Micropaleontology 35, 105-140, doi: 10.1016/S0377-8398 (98)00013-9.

Bjørklund K.R., Itaki T. \& Dolven J.K. 2014. Per Theodor Cleve: a short résumé and his radiolarian results from the Swedish expedition to Spitsbergen in 1898. Journal of Micropalaeontology 33, 59-93, doi: 10.1144/ jmpaleo2012-024.

Bjørklund K.R., Kruglikova S.B. \& Anderson O.R. 2012. Modern incursions of tropical Radiolaria into the Arctic Ocean. Journal of Micropalaeontology 31, 139-158, doi: 10.1144/0262-821X11-030.

Boyer T., Levitus S., Garcia H., Locarnini R.A., Stephens C. \& Antonov J. 2004. Objective analyses of annual, seasonal, and monthly temperature and salinity for the world ocean on a 1/4-degree grid. International Journal of Climatology 25 , 931-945, doi: 10.1002/joc.1173.

Broecker W.S. 1997. Thermohaline circulation, the Achilles heel of our climate system: will man-made $\mathrm{CO}_{2}$ upset the current balance? Science 278, 1582-1588, doi: 10.0.4.102/ science.278.5343.1582.

Bronk Ramsey C. 2008. Deposition models for chronological records. Quaternary Science Reviews 27, 42-60, doi: 10.1016/j.quascirev.2007.01.019.

Bronk Ramsey C. 2009. Bayesian analysis of radiocarbon dates. Radiocarbon 51, 337-360, doi: 10.1017/S00338 22200033865.
Bronk Ramsey C. \& Lee S. 2013. Recent and planned developments of the program OxCal. Radiocarbon 55, 720-730, doi: 10.1017/S0033822200057878.

Cabedo-Sanz P., Belt S.T., Knies J. \& Husum K. 2013. Identification of contrasting seasonal ice conditions during the Younger Dryas. Quaternary Science Reviews 79, 74-86, doi: 10.1016/j.quascirev.2012.10.028.

Cleve P.T. 1899. Plankton collected by the Swedish Expedition to Spitzbergen in 1898. Kongliga Svenska Vetenskaps Akademiens Handlingar 32, 1-51.

Cleve P.T. 1900. Notes on some Atlantic plankton-organisms. Kongliga Svenska Vetenskaps Akademiens Handlingar 34, $1-22$.

Dolven J.K. \& Bjørklund K.R. 2001. An early Holocene peak occurrence and recent distribution of Rhizoplegma boreale (Radiolaria): a biomarker in the Norwegian Sea. Marine Micropaleontology 42, 25-44, doi: 10.1016/ S0377-8398(01)00011-1.

Dolven J.K., Bjørklund K.R. \& Itaki T. 2014. Jørgensen's polycystine radiolarian slide collection and new species. Journal of Micropalaeontology 33, 21-58, doi: 10.1144/ jmpaleo2012-027.

Dolven J.K., Cortese G. \& Bjørklund K. 2002. A high-resolution radiolarian-derived paleotemperature record for the Late Pleistocene-Holocene in the Norwegian Sea. Paleoceanography 17, article no. 1072, doi: 10.1029/2002PA000780.

Ebbesen H. \& Hald M. 2004. Unstable Younger Dryas climate in the northeast North Atlantic. Geology 32, 673-676, doi: 10.1130/G20653.1.

Eldevik T., Risebrobakken B., Bjune A.E., Andersson C., Birks H.J.B., Dokken T.M., Drange H., Glessmer M.S., Li C., Nilsen J.E.Ø., Otterå O.H. Richter K. \& Skagseth Ø. 2014. A brief history of climate-the northern seas from the Last Glacial Maximum to global warming. Quaternary Science Reviews 106, 225-246, doi: 10.1016/j. quascirev.2014.06.028.

Goll R.M. \& Bjørklund K.R. 1974. Radiolaria in surface sediments of the South Atlantic. Micropaleontology 20, 38-75, doi: $10.2307 / 1485099$.

Haflidason H., Sejrup H.P., Kristensen D.K. \& Johnsen S. 1995. Coupled response of the late glacial climatic shifts of northwest Europe reflected in Greenland ice cores: evidence from the northern North Sea. Geology 23, 1059-1062, doi: 10.1130/0091-7613(1995)023<1059: CROTLG>2.3.CO;2.

Hald M. \& Vorren T.O. 1984. Modern and Holocene foraminifera and sediments on the continental shelf off Tromsø, north Norway. Boreas 13, 133-154, doi: 10.1111/j.15023885.1984.tb00067.x.

Hammer Ø., Harper D.A.T. \& Ryan P.D. 2001. PAST: paleontological statistics software package for education and data analysis. Palaeontologia Electronica 4, article no. 1.

Hughen K.A., Baillie M.G.L., Bard E., Beck J.W., Bertrand C.J.H., Blackwell P.G., Buck C.E., Burr G.S., Cutler K.B., Damon P.E., Edwards R.L., Fairbanks R.G., Friedrich M., Guilderson T.P., Kromer B., McCormac G., Manning S., Ramsey C.B., Reimer P.J., Reimer R.W., Remmele S., Southon J.R., Stuiver M., Talamo S., Taylor F.W., van der 
Plicht J. \& Weyhenmeyer C.E. 2004. Marine04 marine radiocarbon age calibration, $0-26 \mathrm{cal}$ kyr BP. Radiocarbon 46, 1059-1086, doi: 10.1017/S0033822200033002.

Imbrie J. \& Kipp N.G. 1971. A new micropaleontological method for quantitative paleoclimatology: application to a late Pleistocene Caribbean core. In K.K. Turekian (ed.): The Late Cenozoic glacial ages. Pp. 71-182. New Haven, CT: Yale University Press.

Jansen E. \& Bjørklund K.R. 1985. Surface ocean circulation in the Norwegian Sea 15,000 B.P. to present. Boreas 14, 243-257, doi: 10.1111/j.1502-3885.1985.tb00729.x.

Jørgensen E. 1900. Protophyten und Protozoen im Plankton aus der Norwegischen Westküste. (Protophytes and Protozoa in the plankton of the west coast of Norway.) Bergens Museums Aarbog 1899, 51-95.

Jørgensen E. 1905. The protist plankton and the diatoms in bottom samples. Bergens Museums Skrifter 1905, 49-151.

Knies J. 2005. Climate-induced changes in sedimentary regimes for organic matter supply on the continental shelf off northern Norway. Geochimica et Cosmochimica Acta 69, 4631-4647, doi: 10.1016/j.gca.2005.05.014.

Knies J., Hald M., Ebbesen H., Mann U. \& Vogt C. 2003. A deglacial-middle Holocene record of biogenic sedimentation and paleoproductivity changes from the northern Norwegian continental shelf. Paleoceanography 18, article no. 1096, doi: 10.1029/2002PA000872.

Krebs C.J. 1989. Ecological methodology. New York: Harper \& Row.

Kruglikova S.B., Bjørklund K.R., Dolven J.K., Hammer Ø. \& Cortese G. 2010. High-rank polycystine radiolarian taxa as temperature proxies in the Nordic seas. Stratigraphy 7 , 265-281.

Legendre P. \& Legendre L. 1998. Numerical ecology. Amsterdam: Elsevier.

Matul A. \& Mohan R. 2017. Distribution of polycystine radiolarians in bottom surface sediments and its relation to summer sea temperature in the high-latitude North Atlantic. Frontiers in Marine Science 4, article no. 330, doi: 10.3389/fmars.2017.00330.

Matul A.G. \& Yushina I.G. 1999. Radiolarians in North Atlantic sediments. Reports on Polar Research 306, 35-45.

Mayewski P.A., Meeker L.D., Whitlow S., Twickler M.S., Morrison M.C., Alley R.B., Bloomfield P. \& Taylor K. 1993. The atmosphere during the Younger Dryas. Science 261, 195-197, doi: 10.1126/science.261.5118.195.

Petrushevskaya M.G. \& Bjørklund K.R. 1974. Radiolarians in Holocene sediments of the Norwegian-Greenland seas. Sarsia 57, 33-46, doi: 10.1080/00364827.1974.10411269.

Rasmussen S.O., Andersen K.K., Svensson A.M., Steffensen J.P., Vinther B.M., Clausen H.B., SiggaardAndersen M.-L., Johnsen S.J., Larsen L.B., Dahl-Jensen D., Bigler M., Röthlisberger R., Fischer H., Goto-Azuma K., Hansson M.E. \& Ruth U. 2006. A new Greenland ice core chronology for the last glacial termination. Journal of Geophysical Research-Atmospheres 111, D06102, doi: 10.1029/2005JD006079.
Rasmussen S.O., Vinther B.M., Clausen H.B. \& Andersen K.K. 2007. Early Holocene climate oscillations recorded in three Greenland ice cores. Quaternary Science Reviews 26, 1907-1914, doi: 10.1016/j.quascirev.2007.06.015.

Reimer P.J., Baillie M.G.L., Bard E., Bayliss A., Beck J.W., Blackwell P.G., Bronk Ramsey C., Buck C.E., Burr G.S., Edwards R.L., Friedrich M., Grootes P.M., Guilderson T.P., Hajdas I., Heaton T.J., Hogg A.G., Hughen K.A., Kaiser K.F., Kromer B., McCormac F.G., Manning S.W., Reimer R.W., Richards D.A., Southon J.R., Talamo S., Turney C.S.M., van der Plicht J. \& Weyhenmeyer C.E. 2009. IntCal09 and Marine09 radiocarbon age calibration curves, 0-50,000 years cal BP. Radiocarbon 51, 1111-1150, doi: 10.1017/S0033822200034202.

Reimer P.J., Bard E., Bayliss A., Beck J.W., Blackwell P.G., Bronk Ramsey C., Buck C.E., Cheng H., Edwards R.L., Friedrich M., Grootes P.M., Guilderson T.P., Haflidason H., Hajdas I., Hatté C., Heaton T.J., Hoffmann D.L., Hogg A.G., Hughen K.A., Kaiser K.F., Kromer B., Manning S.W., Niu M., Reimer R.W., Richards D.A., Scott E.M., Southon J.R., Staff R.A., Turney C.S.M. \& van der Plicht J. 2013. IntCal1 3 and Marine 13 radiocarbon age calibration curves 0-50,000 years cal BP. Radiocarbon 55, 1869-1887, doi: 10.2458/azu_js_rc.55.16947.

Risebrobakken B., Jansen E., Andersson C., Mjelde E. \& Hevrøy K. 2003. A high-resolution study of Holocene paleoclimatic and paleoceanographic changes in the Nordic seas. Paleoceanography 18, article no. 1017, doi: 10.1029/2002PA000764.

Schröder O. 1909. Die nordischen Spumellarien, Teil II: Unterlegion Sphaerellaria. (The Nordic Spumellaria. Part II: sublegion Sphaerellaria.) In K. Brandt \& C. Apstein (eds.): Nordisches plankton. Bd. 7, XVII. (Nordic plankton. Vol. 7, XVII.) Pp. 1-66. Kiel: Lipsius \& Tischer.

Schröder O. 1914. Die nordischen Nassellarien. (The Nordic Nassellaria.) In K. Brandt \& C. Apstein (eds.): Nordisches plankton. Bd. 7, XVII. (Nordic plankton. Vol. 7, XVII.) Pp. 67-146. Kiel: Lipsius \& Tischer.

Slagstad D., Tande K.S. \& Wassmann P. 1999. Modelled carbon fluxes as validated by field data on the north Norwegian shelf during the productive period in 1994. Sarsia 84, 303-317, doi: 10.1080/00364827.1999.10420434.

Stuiver M., Reimer P.J. \& Reimer R.W. 2005. CALIB 6.0. WWW programme and documentation accessed at http:// calib.org/calib in 2018.

Telford R.J., Heegaard E. \& Birks H.J.B. 2004. All age-depth models are wrong: but how badly? Quaternary Science Reviews 23, 1-5, doi: 10.1016/j.quascirev.2003.11.003.

Ter Braak C.J.F. \& Juggins S. 1993. Weighted averaging partial least squares (WA-PLS): an improved method for reconstructing environmental variables from species assemblages. Hydrobiology 269/270, 485-502, doi: 10.1007/BF00028046.

Wassmann P., Andreassen I.J. \& Rey F. 1999. Seasonal variation of nutrients and suspended biomass on a transect across Nordvestbanken, north Norwegian shelf, in 1994. Sarsia 84, 199-212, doi: 10.1080/00364827.1999.10420426. 